Research Article

\title{
Experimental Study and Numerical Simulation on Failure Process of Reinforced Concrete Box Culvert
}

\author{
Yafeng Gong, ${ }^{1}$ Yulin Ma, ${ }^{1}$ Guojin Tan ${ }^{D},{ }^{1}$ Haipeng $\mathrm{Bi}^{1}{ }^{1}$ Yunze Pang, ${ }^{1}$ and Chen $\mathrm{Ma}^{2}$ \\ ${ }^{1}$ Jilin University, College of Transportation, Changchun 130025, China \\ ${ }^{2}$ Jilin Traffic Planning and Design Institute, Changchun 130025, China \\ Correspondence should be addressed to Guojin Tan; tgj@jlu.edu.cn
}

Received 16 December 2019; Revised 14 June 2020; Accepted 27 July 2020; Published 13 August 2020

Academic Editor: Zahid Hossain

Copyright (C) 2020 Yafeng Gong et al. This is an open access article distributed under the Creative Commons Attribution License, which permits unrestricted use, distribution, and reproduction in any medium, provided the original work is properly cited.

Culvert is an important part of roads whose healthy operation is related to the efficiency and safety of road transportation. Therefore, it is very important to evaluate the safety of culvert structure by load test. Four types of prefabricated reinforced concrete box culverts (integral BC, round hinged BC, flat seam BC, and mortise BC) were designed in this paper. By designing a scale model test, the sensor system was used to test the mechanical properties of $\mathrm{BC}$, which included dial indicators, strain gauges, and a pressure sensor. The finite element analysis based on material nonlinearity and contact nonlinearity of round hinged $\mathrm{BC}$ and integral BC was carried out. After validating the finite element models, mechanical properties of reinforcement and concrete of $\mathrm{BCs}$ were analyzed. The experimental results show that the failure mode of $\mathrm{BC}$ was tensile failure of concrete at the bottom of top slab under bending action, and integral $\mathrm{BC}$ had the maximum carrying capacity. The contact behaviour of sliding and rotating at hinge joints caused the first principal tensile stress of concrete at the internal surface of the side wall below hinge joints.

\section{Introduction}

Culvert is a common reinforced concrete structure in highway engineering, which is often used for drainage or as a passage for people and cars. As the number and weight of vehicles in highways increase, the safety of culvert operations is threatened. Therefore, it is necessary to regularly test the mechanical properties of culverts in highways [1]. Reinforced concrete box culverts (BCs) are an important part of highway industrial construction, which has the characteristics of factory prefabrication and on-site assembly construction. However, any inadequacy in the design or construction of prefabricated BCs can cause problems such as misalignment and deep cracks in the structure [2]. Therefore, an accurate analysis of the mechanical properties of reinforced concrete BCs should be established.

In the past period of time, domestic and foreign scholars had carried out a lot of research studies on soil pressure, soil arching effect, and soil-culvert interaction of BCs [3-5]. These researches showed that the material properties of soil and culverts, the span and thickness of culverts, the height of culverts, the depth of burial, and external pressure all had an effect on the mechanical properties of culverts [6-9]. Kim and Yoo [10] studied the influence of foundation on the mechanical properties of BCs based on finite element simulation technology. The prediction equation of the soilculvert interaction factor was derived according to the numerical data of the BCs under embankment, trench, and imperfect trench installation methods. Chen et al. [11] studied the influence of backfill soil properties on the vertical soil pressure of culverts. This study showed that the vertical soil pressure coefficient at the top of the culvert was significantly different from the recommended value of the Chinese General Code for Design of Highway Bridges and Culverts (JTG D60-2004) based on linear theory. Orton et al. [12] conducted field tests on 10 reinforced concrete BCs. The results showed that the impact of live load on the culvert decreased with the increase of the thickness of the fill, but when the height of the fill exceeds $1.82 \mathrm{~m}$, it could be ignored as the effect of live load. Acharya et al. [13] researched the influence of culvert deflection on axial load and position under static load, and the study showed that the maximum 
displacement of culvert occurred in midspan. Moreover, the maximum deflection of culvert after paving concrete pavement was three times smaller than that before paving, and the pavement affected the load and deflection distribution of culvert.

Due to the richness of the culvert form, it is necessary to analyze the structural mechanical properties of culvert based on research of the influence of soil pressure and groove shape on the backfill pressure at the top of culvert. Grag et al. [14-16] detected the failure process of six full-size BCs by means of hierarchical loading and analyzed the development of culvert cracks based on the nonlinear finite element model. It concluded that shear was not the governing behavioural mode for concrete BCs, and the live load distribution equation along with the provisions for shear transfer devices for BCs reported in AASHTO HS-20 was also needed to be modified. In order to study the ultimate bearing capacity and fatigue life of culverts, Moradi et al. [17] established a BC model based on geometric and physical nonlinearity and analyzed the influence of concrete compressive strength, reinforcement ratio, and geometric structure on box culverts. In the study by Maximos et al. [18], structural properties and fatigue behaviour of BCs under cyclic loads were experimentally investigated, which indicated that the fatigue of reinforced concrete BC had the least effect, and some amendments to fatigue regulations of the AASHTO standard were recommended. Abuhajar et al. [19] studied factors that had an effect on soil arching by conducting experimental and analytical research studies. In addition to soil fill height, they determined that soil arching depended on culvert thickness, elastic modulus of soil, and position ratio. Shatnawi et al. [20] used a finite-element method to study the behaviour of reinforced concrete BCs with different dimensions and thicknesses under different soil fill heights. Castaldo et al. [21] used a nonlinear finite element model to study the failure modes of reinforced concrete beams with web openings, which were affected by the material properties defined in the model. His study described some proposals regarding the safety formats for nonlinear finite element analysis within the approach of the global resistance format to estimate the design strength of reinforced concrete structure. In these studies, culverts were usually integrated cast, but culverts in this paper were prefabricated components, which were formed by sectioning and were assembled as integral force-bearing members. The study of structural mechanical properties of prefabricated reinforced concrete box culverts during failure was novel.

This paper took the prefabricated reinforced concrete BC used in the highway of Songyuan-Tongyu section of Jilin Province (China) as the prototype. Four different types of $\mathrm{BCs}$ were produced with a model ratio of $1: 4$, including an integral $\mathrm{BC}$, a round hinged $\mathrm{BC}$, a flat seam $\mathrm{BC}$, and a mortise BC. At the same time, a detachable sensor system was used to record changes in the mechanical properties of BCs, which included dial gauges, strain gauges, and a pressure sensor. Firstly, the failure process of BC was studied by means of step-by-step loading, including the bearing capacity, crack development, and deflection changes of BCs. Then, the finite element analysis of the round hinged BC and the integral $\mathrm{BC}$ based on material nonlinearity and contact nonlinearity was carried out. Based on the validity of the finite element model, the axial force of reinforcement and concrete stress of BCs were analyzed. According to experimental data, this paper provided some references for the design of prefabricated reinforced concrete box culverts.

\section{Experimental Study}

2.1. Experimental Model. Based on physical engineering, the test will shrink the prefabricated reinforced concrete BCs by a ratio of $1: 4$, with reference to the prefabricated subway structure design [22]. The structural dimensions of the box culvert prototype are shown in Figure 1.

Four measured models of prefabricated reinforced concrete BCs were designed, and the parameters of each model are shown in Table 1. Similarity theory was the basis of model test whose basic principle was to establish a certain scale model by using materials with similar mechanical properties. Then, it was tested to observe the stress, strain, displacement, and failure of the model, so as to analyze and predict the actual situation of the prototype. The geometric dimensions of the $\mathrm{BC}$ model were determined and the structural design drawings of different types of scale models were obtained by the dimensional analysis method based on the three laws of similarity from similarity theory, as shown in Figure 2.

2.2. Material Properties. The design standard of concrete of BCs was C40, and the required material parameters are provided in Table 2 . The longitudinally stressed reinforcement of the $\mathrm{BC}$ was $6 \mathrm{~mm}$, the diameter of the erection reinforcement was $2 \mathrm{~mm}$, and the diameter of the constructional reinforcement at the joint was $4 \mathrm{~mm}$. In addition, the reinforcement rate of the model structure is the same as that of the prototype, which was $0.86 \%$. Three sizes of $150^{*} 150^{*} 150 \mathrm{~mm}$ were poured to determine the actual compressive strength of concrete according to the method specified in Test Methods for Mechanical Properties of Ordinary Concrete (GB/T50081-2002). The cubic compressive strength of concrete was $41.5 \mathrm{MPa}$, the axial compressive strength was $31.5 \mathrm{MPa}$, and the axial tensile strength was $3.1 \mathrm{MPa}$. At the same time, on the basis of the method specified in Metal Material Tensile Test Method (GB/T2282002), the yield strength of $\varphi 6$ steel bar was $214 \mathrm{MPa}$ and the ultimate strength was $307 \mathrm{MPa}$.

2.3. Loading and Measurements. The main parameters measured in this experiment were the strain on the top slab of the $\mathrm{BC}$, the deformation of the structure, and the cracking of the concrete. A set of instrumented loading and measuring devices was used for this study. The experiment was carried out by using a $1000 \mathrm{kN}$ microcomputer-controlled electrohydraulic servo tester (China, Jilin, Jinli Testing Technology Co., Ltd.). The strain on the top slab of the BC was observed by DH-3816 static stress test and analysis system (China, Jiangsu, Donghua Testing Technology Co., Ltd.). The displacement of the structure was observed by 


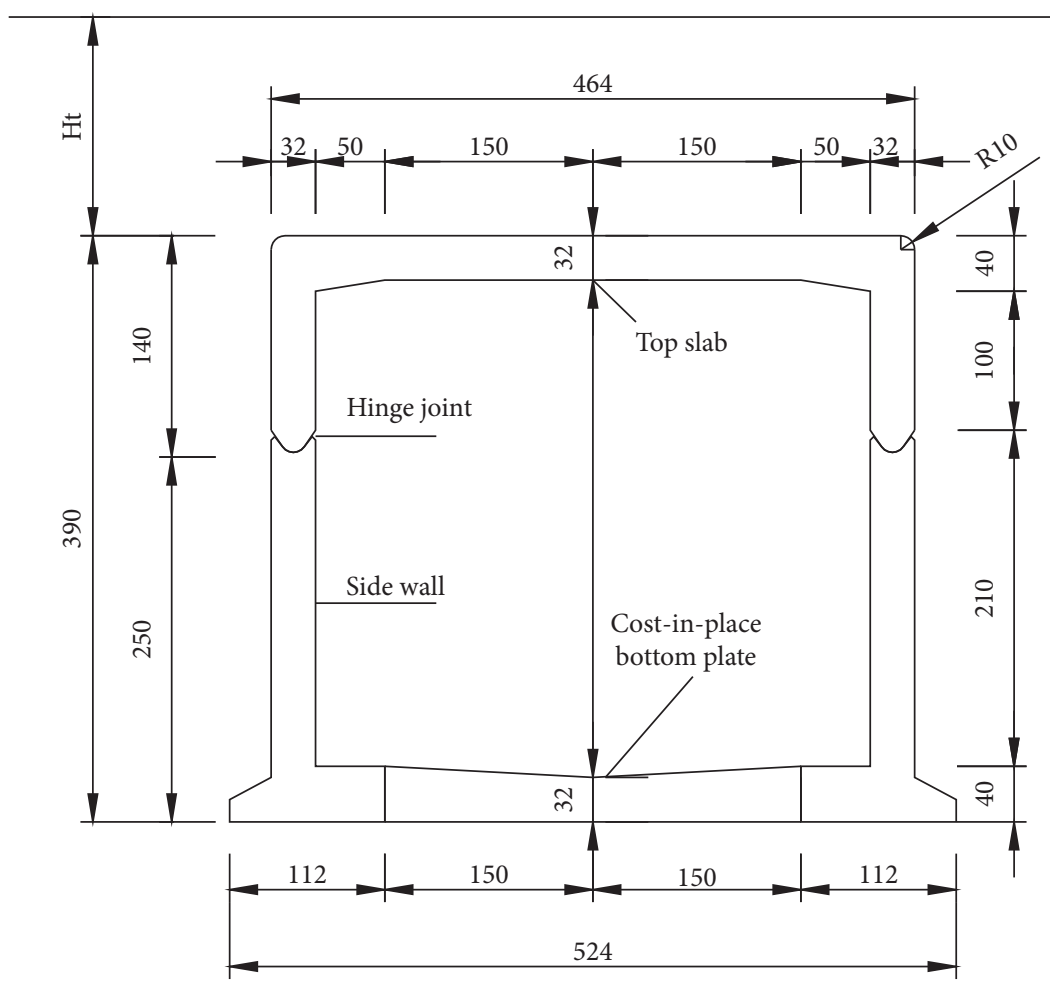

(a)

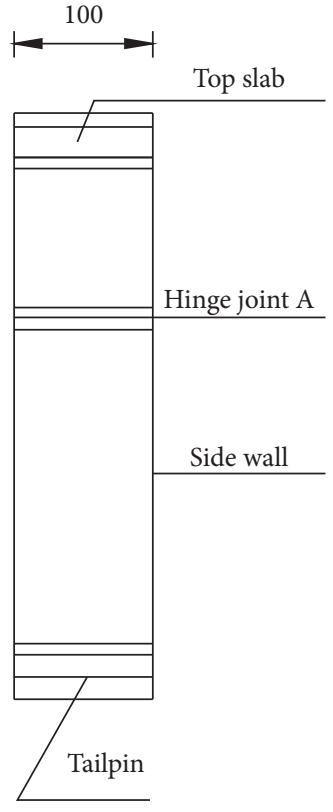

(b)

FIgURE 1: Structural dimensions of prefabricated BCs (unit: cm). (a) Vertical view. (b) Lateral view.

TABLE 1: List of scale models.

Numbers $\begin{aligned} & \text { The size of structure } \\ & \begin{array}{c}\text { Span: } 116 \mathrm{~cm} \\ \text { High wall: } 97.5 \mathrm{~cm}\end{array} \\ & \text { Culvert length: } 25 \mathrm{~cm}\end{aligned}$ Presence of hinge joints
3

DH-3817 dynamic and static strain test system (China, Jiangsu, Donghua Testing Technology Co., Ltd.). The HCCK101 crack width observer (China, Beijing, Haichuang Gaoke Company) was used to record the crack width produced by the concrete.

The experimental loading device is a reaction force frame composed of two steel columns and a beam, which is shown in Figure 3(a). The loading cylinder is attached to the beam, the short column is below it, followed by a $1000 \mathrm{kN}$ load cell, and finally the leveling device. The size of the load plate is $600 * 120 * 250 \mathrm{~mm}$, and two bars with a diameter of $25 \mathrm{~mm}$ are welded underneath. The distance between two bars is $50 \mathrm{~cm}$, which is used to describe the wheelbase of cars. In order to study the failure modes and failure mechanisms of culverts under ultimate load, the failure experiments under force control mode were carried out. The experiment adopted the loading mode of step-by-step loading, and the initial load increment was $5 \mathrm{kN}$. When the load reached $10 \mathrm{kN}$, the load increment became $3 \mathrm{kN}$ in order to more accurately detect the response of the $\mathrm{BC}$, until the experimental BC was completely destroyed. The loading time of each stage load was $3 \mathrm{~min}$, then the load was held for $5 \mathrm{~min}$, and the mechanical response of the $\mathrm{BC}$ under the current load was recorded.

The dial indicator (China, Jiangsu, Puyang Instrument Factory) has a measuring range of $50 \mathrm{~mm}$ and a measuring accuracy of $0.01 \mathrm{~mm}$. It was connected by an insulated three-conductor wire to DH-3817. Eight dial 

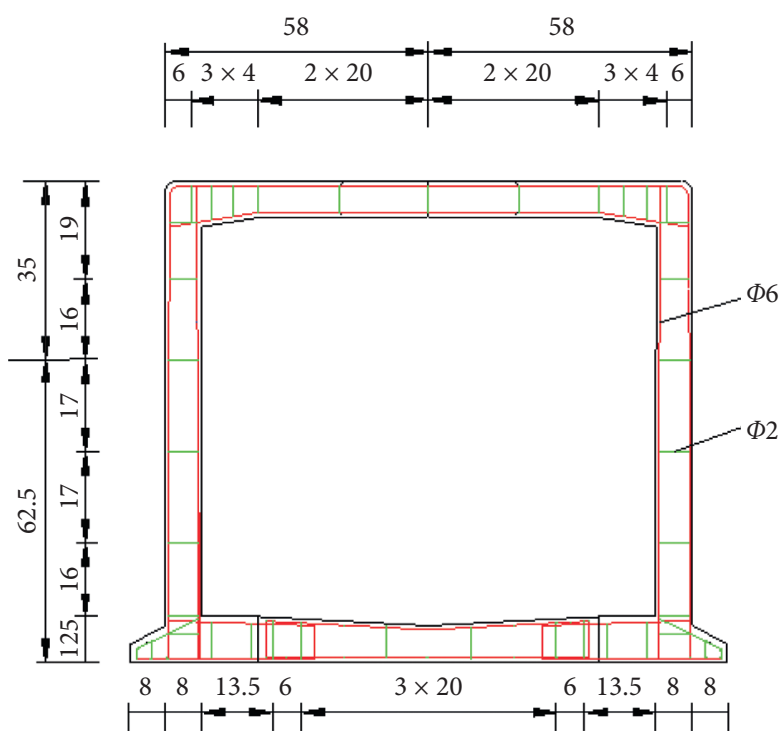

(a)
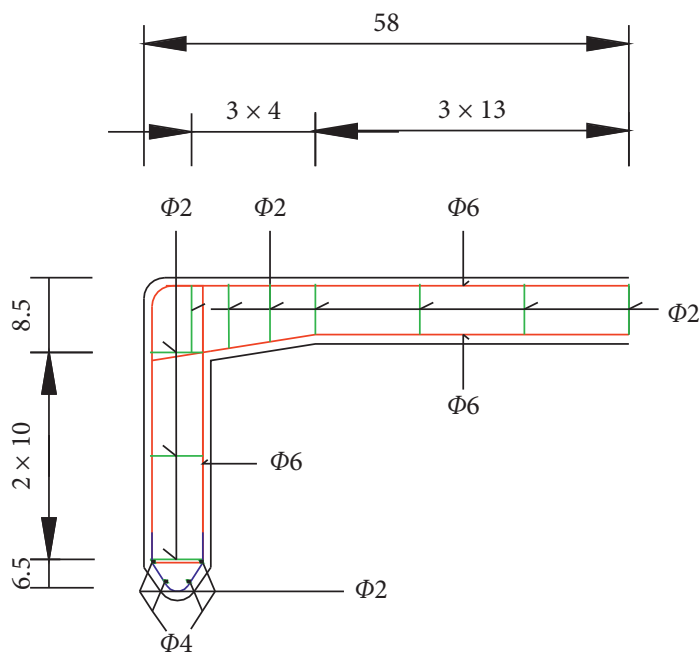

(c)
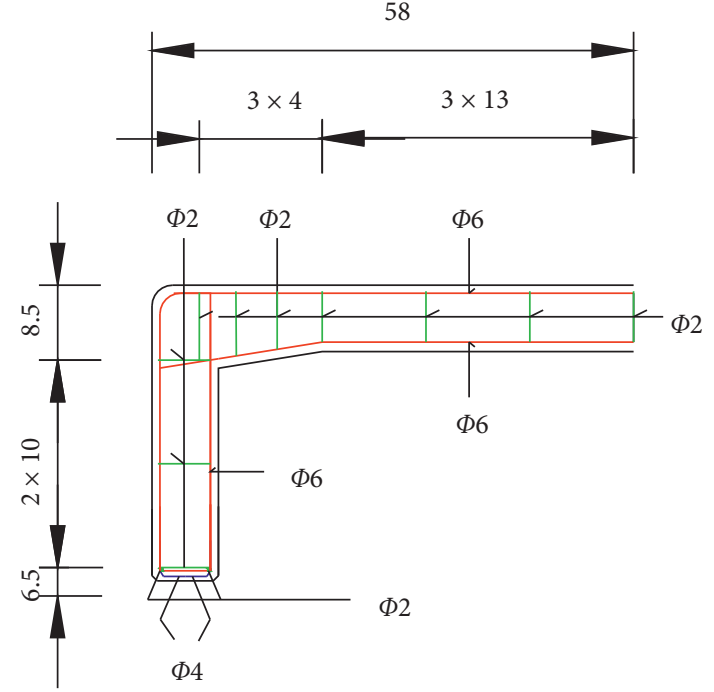

(b)
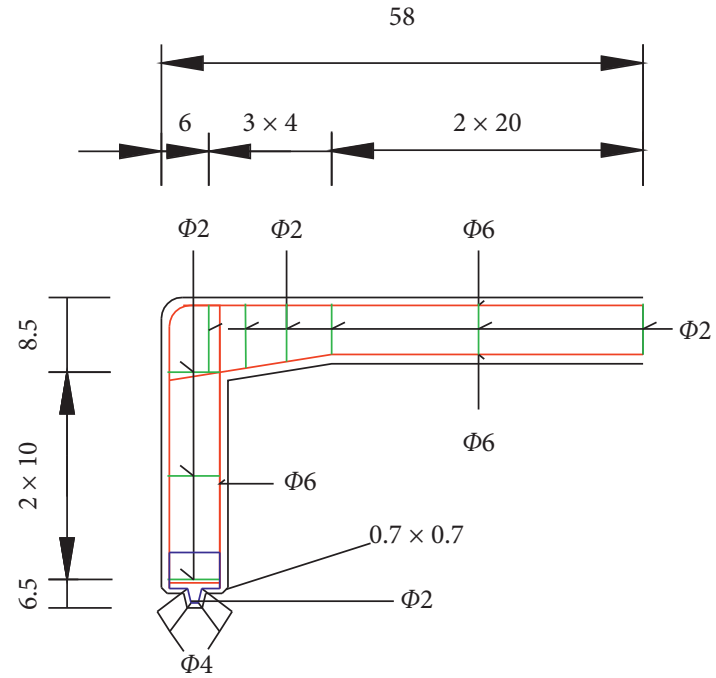

(d)

Figure 2: Structural design of prefabricated BCs (unit: $\mathrm{cm}$ ). (a) Integral type. (b) Feature of hinged joint of flat seam type. (c) Feature of hinged joint of round hinged type. (d) Feature of hinged joint of mortise type.

TABLE 2: The concrete mix ratio.

\begin{tabular}{lccccc}
\hline Concrete label & Water $\left(\mathrm{kg} / \mathrm{m}^{3}\right)$ & Cement $\left(\mathrm{kg} / \mathrm{m}^{3}\right)$ & Sand $\left(\mathrm{kg} / \mathrm{m}^{3}\right)$ & Stone $\left(\mathrm{kg} / \mathrm{m}^{3}\right)$ & Water reducing agent $(\%)$ \\
\hline C40 & 184 & 418 & 629 & 1169 & 0.2 \\
\hline
\end{tabular}

indicators were evenly distributed along BC side wall, but when the side wall had hinge joints, it was necessary to encrypt measurements of displacement at hinge joints. Three dial indicators were arranged in the internal surface of the top slab where the bending moment was likely to be the largest, respectively, in the midspan, $1 / 4$ and $3 / 4$ positions. Dial indicators were all connected to the steel plates around $\mathrm{BC}$ by magnetic tables. The steel plates did not shift during the experiment. Strain gauges were connected by insulated wires to the DH-3816, which were placed on the mid-span, $1 / 4$ and $3 / 4$ spans, respectively. The crack width observer consisted of an illuminated-end camera and a display panel. The magnification of the camera was 40 times and the display panel was marked with a scale. The maximum range is $2 \mathrm{~mm}$ and the error is $0.01 \mathrm{~mm}$. The concrete on the side of the $\mathrm{BC}$ was smoothed with sandpaper before the start of the experiment in order to better record the initiation and development of cracks, and a $3 * 3 \mathrm{~mm}$ grid was drawn. The layout of the instrument is shown in Figure 3(b). 


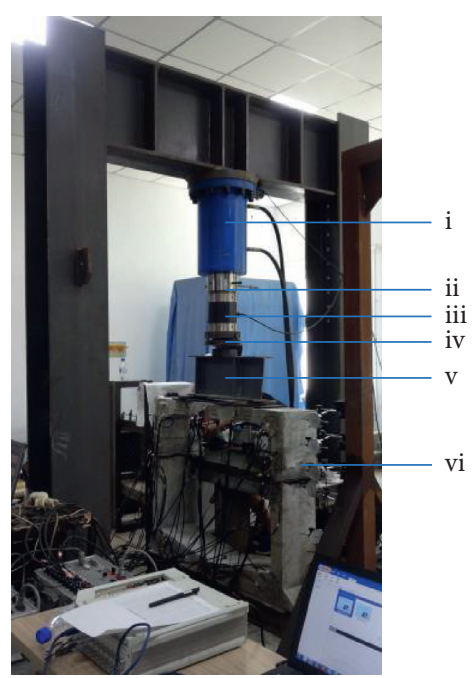

(a)

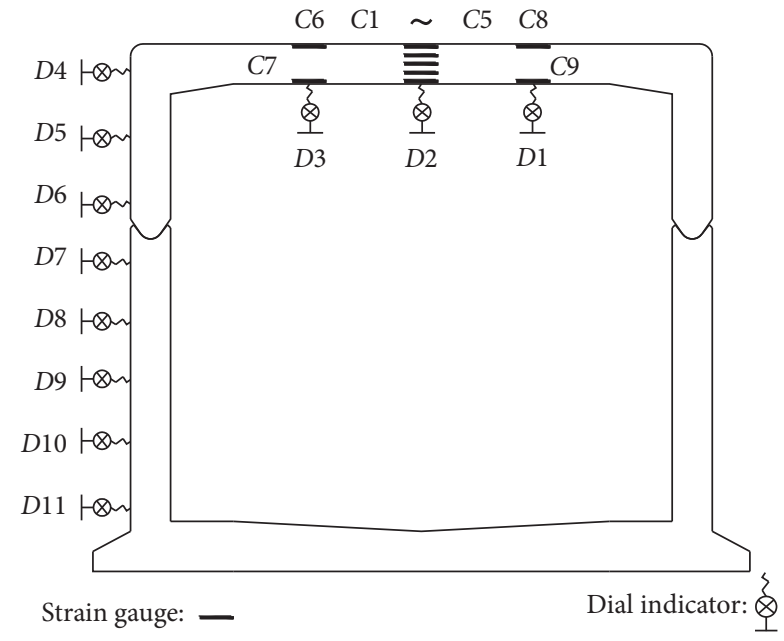

(b)

Figure 3: Loading and measuring. (a) The diagram of test loading. (i) Load cylinder. (ii) Stub column. (iii) Load cell. (iv) Leveling Device. (v) Load plate. (vi) Test specimen. (b) The arrangement of measuring points.

\section{Results and Discussion}

3.1. Failure Process and Development of Cracks in BC Structures. BC structure experienced three stages of elasticity, cracking, and failure with the change of loading. The cracking load was used to distinguish the elastic stage from the cracking stage, while the ultimate load was used to define the failure load of the structure. The load results were shown in Table 3. In order to study the cracking of the top slab concrete, the side surface of the top slab of the BC was taken as the recording surface, and the intersection of the internal surface of the top slab and the external surface of the side wall were taken as the origin of the coordinate axis to record the initiation and development of the crack. Figure 4 shows the distribution of cracks.

It could be seen from Table 3 and Figure 4 that the round hinged BC first produced cracks. When the load was $9.2 \mathrm{kN}$, the concrete produced the first crack, which was located in the middle section of the top slab. And the crack extended from the observation surface to the back through the surface of the top slab. When the load was $14.2 \mathrm{kN}$, the second and third cracks were generated, which were located directly below the loading plate and belonged to the symmetric crack. At the same time, the first crack width was $0.22 \mathrm{~mm}$, and the length was $4.4 \mathrm{~cm}$, which was half the thickness of the top slab. At the load of $19.5 \mathrm{kN}$, the fourth crack occurred, and the previous three cracks continued to develop. When the load was $22 \mathrm{kN}$, the first, second, and third cracks had penetrated the top slab, and the structure lost its carrying capacity. The development process of integral type, flat seam type, and mortise type concrete cracks was similar to round hinged type, but their load carrying capacity was better than round hinged type. Moreover, the load they generated cracks was much larger than that of the round hinged structure. However, the four structures had a common feature, whose failure modes were tensile damage caused by the bending of the top slab. Excessive or oversized cracks would not only cause user anxiety, but affect the service life of structure. With the purpose of preventing oversized shrinkage cracks, longitudinal horizontal reinforcement should be added to the top slab during design. In the process of structural health monitoring, it is important to check the crack development of the concrete on the internal surface of the top slab.

3.2. Midspan Deflection-Load Curve of Top Slab. During the use of BCs, excessive deflection will affect the safety of the structure. In order to study the mechanical properties of different types of BCs, dial indicators were placed at the midspan of the internal surface of the top slab. The test results are shown in Figure 5.

It can be seen from Figure 5 that the deflection curves of the midspans of various types of BCs exhibit a nonlinear growth trend with the increase of the load, and four curves can be divided into elastic working state and plasticity working state. In the elastic working stage, there is no crack on the culvert, and the midspan deflection of the top slab in the culvert is linear with the load. Except for the initial stiffness of the round hinged type BC, the initial stiffness of the other three types of BCs is maintained at a high level. As the load continues to increase, $\mathrm{BC}$ enters the second working state, which is the plasticity working state. Cracks begin to appear in various types of BCs. Moreover, the number of cracks begins to increase and the stiffness of $\mathrm{BC}$ begins to decay. BC loses its working ability when the deflection of the midspan of the top slab of BC increases sharply. It can be seen from Figure 5 that, under the same reinforcement ratio and concrete strength, the structural performance of the integral type $\mathrm{BC}$ is the best, followed by the flat seam type $\mathrm{BC}$ and the mortise type $\mathrm{BC}$, and the worst is the round hinged type $\mathrm{BC}$. Therefore, it is recommended to use integral type structure in the design of the BC structure to avoid the round hinged type structure. Moreover, it is necessary to focus on 
TABLE 3: Cracking load and ultimate load of BC.

\begin{tabular}{lcccc}
\hline Structure type & Cracking load & & \multicolumn{2}{c}{ Ultimate load } \\
& Crack location of top slab & Load $(\mathrm{kN})$ & Midspan deflection of top slab $(\mathrm{mm})$ \\
\hline Flat seam type & 17.3 & $0.32 L^{1}$ & 26.4 & 12.41 \\
Round hinged type & 9.2 & $0.48 L$ & 22.0 & 19.21 \\
Integral type & 20.0 & $0.38 L$ & 32.0 & 7.21 \\
Mortise type & 14.0 & $0.36 L$ & 23.0 & 9.04 \\
\hline
\end{tabular}

${ }^{1} L$ is the span of the top slab, and the length is $1.18 \mathrm{~m}$.

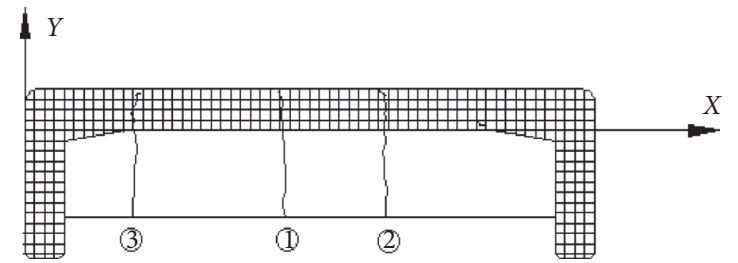

(a)

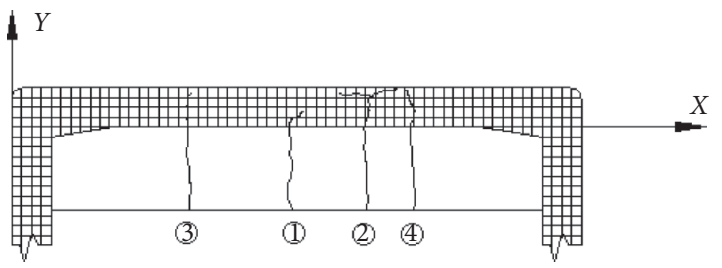

(c)

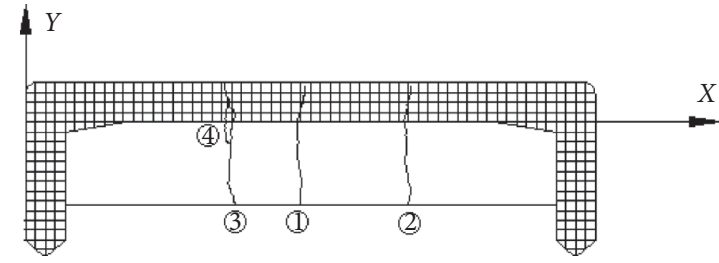

(b)

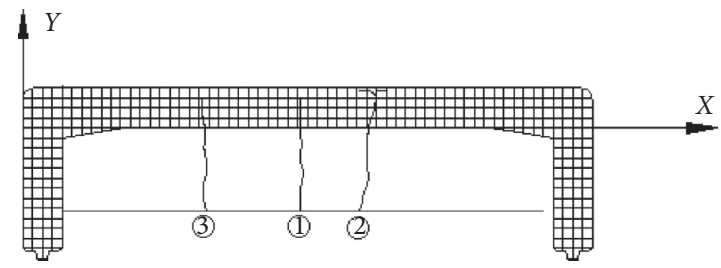

(d)

Figure 4: The crack distribution of prefabricated BC structure. (a) Flat seam type. (b) Round hinged type. (c) Integral type. (d) Mortise type. (1), (2), (3), and (4) are the order of crack initiation.

observing the deflection curve of the top slab in the health detection process of the $\mathrm{BC}$ structure. And the working state of $\mathrm{BC}$ can be measured to determine the safety of BC by plotting the long-term midspan of top slab deflection curve.

3.3. Displacement Distribution Rule of Side Wall of BC. BCs are short-span structures, and their mechanical properties are affected by side walls. On the one hand, side walls constrain vertical deformation of top slab, and on the other hand, they bear the lateral pressure of the soil to BC. The distribution rules of the displacement of the side walls of various BC structures are shown in Figure 6.

In Figure 6, a positive value of the $X$-axis indicates that the side wall is deformed outward, and a negative value indicates that the side wall is deformed inward. Side wall in rotated and horizontal direction is deformed due to vertical downward displacement of top slab under load. The horizontal displacement of four types of BC side walls presents a nonlinear distribution along the wall. The change of horizontal displacement of the side walls of BCs from bottom to top shows a regular pattern that increases first and then decreases. The maximum horizontal displacement of the integral BC begins at $3 / 5$ of the height of the side wall. As the load increases, the position of the maximum horizontal displacement increases upward along the side wall. When the structure is destroyed, the position of the maximum horizontal displacement is $7 / 10$ of the height of the side wall. The maximum horizontal displacement of the $\mathrm{BC}$ side wall of the other three structures occurs at the hinge joints. The maximum horizontal displacement of the side wall of flat seam structure, round hinged structure, and mortise structure is $2.43,4.25$, and 1.63 times that of the integral structure, respectively. Therefore, when designing a BC under a high embankment, it is recommended to use integral structure, followed by mortise structure, and flat seam structure and round hinged structure should not be used. In the case of health monitoring of the $\mathrm{BC}$ structure, the maximum horizontal displacement shall occur within the range of $(3 / 5 \sim 7 / 10) \mathrm{h}$ of the height of side wall for the integral structure. For the side wall with hinge joints, the horizontal displacement at the hinge joints should be observed.

3.4. Variation Law of Strain of Midspan Section in Top Slab. The strain variation law of the midspan section in the top slab can be obtained by sorting and summarizing the strain data of measurement points $C 1, C 2, C 3, C 4$, and $C 5$, and the result is shown in Figure 7.

A positive strain indicates that the concrete is being pulled, and a negative value indicates that the concrete is under pressure. Analysis of Figure 7 shows that, from loading to cracking load, the bending strain variation law of top slab across midspan section of all types of BC structure meets the flat cross-section hypothesis. After the flat seam BC structure cracking, the strain distribution of the top slab across the midspan section shows the nonlinear distribution law, and the position of the neutral 


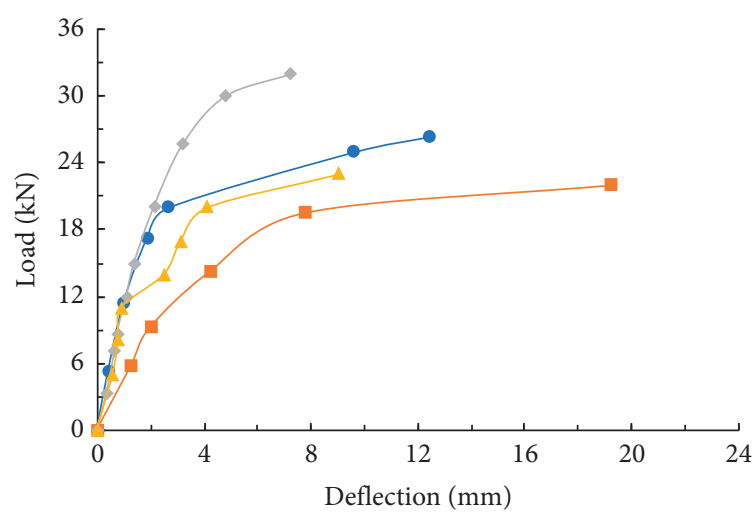

$\rightarrow$ Flat seam type $\quad \rightarrow$ Intergral type
$\rightarrow-$ Round hinged type $\rightarrow-$ Mortise type

Figure 5: The midspan deflection-load curve of top slab of various BCs.

axis increases in the vertical direction with the increase of the load, indicating that the bending and tensile action of the concrete under the section is more obvious. The top slab of the round hinged $\mathrm{BC}$ structure has a small degree of strain change in the elastic working state. There is no obvious change in the neutral axis position, and the bending strain of the upper and lower sections is contrapuntal, indicating that the force of the structure in this working state is more uniform. Before loading to structure cracking, the neutral axis of the midspan section of the integral BC is in the middle of the section. And as the load increases, the neutral axis of the midspan section is raised up in the direction of the wall height. After the mortise BC structure cracking, the strain distribution law of the top slab across the midspan section is linear distribution. The absolute value of the upper and lower bending strains of the section is quite different, and the neutral axis has a large degree of upward shift.

\section{Numerical Simulation}

4.1. Finite Element Model. The finite element model of integral BC and round hinged BC was established by ANSYS. In this paper, the material nonlinearity was considered in the finite element model of integral BC, and the material nonlinearity and boundary nonlinearity were considered in the finite element model of round hinged $\mathrm{BC}$. The constitutive model of concrete adopted the Multilinear Isotropic Hardening model (MISO model). This article calculated the stress-strain relationship of concrete according to the regulations in Code for Design of Concrete Structures (GB50010-2010). In the ANSYS model, only the rising section of the stress-strain curve of concrete was considered, and a multisection broken line was used for simulation. The constitutive model of the reinforcement was Bilinear Kinematic Hardening Model (BKIN model). All the parameters are shown in Figure 8.

The size of the ANSYS model was the same as the scale model test. The concrete adopted nonlinear three-dimensional solid element (Solid65) and the steel adopted space one-dimensional rod unit (Link8). The position of the hinge joint of the Round hinged $\mathrm{BC}$ was provided with surface-tosurface contact, and the target surface and the contact surface were, respectively, Trage170 unit and Conta174 unit. In the modeling process of ANSYS, it was necessary to model the reinforcement and concrete separately, then contacted or coupled the two to form a whole, and participated in the deformation of the force together. The ANSYS models of BCs are shown in Figures 9 and 10. According to the loading method described in 2.3, nodal loads under various working conditions were applied to the ANSYS model. According to the scale model test, the bottom plate of round hinged $\mathrm{BC}$ and integral BC did not produce any displacement in any direction. Therefore, in the ANSYS model, the $X, Y$, and $Z$ displacements of all nodes under the bottom plate were constrained.

4.2. The Validity of Nonlinear Finite Element Model. The curve of the deflection of the top slab of round hinged $\mathrm{BC}$ and integral type $\mathrm{BC}$ with the change of load are graphically drawn in order to compare and analyze the simulated values with the test results, as shown in Figure 11.

As can be seen from Figure 11, the experimental value of the top slab of round hinged BC and integral BC is basically the same as the simulation value; with the increase of load, the experimental value of the top slab deflection is bigger than the simulation value. In the elastic working stage of culverts, the relative errors between the experimental value and the simulated value in round hinged BC and integral BC are $12.5 \%$ and 17.4 , respectively. However, the relative error between two culverts reached $30.2 \%$ and $29.1 \%$ in the plasticity work phase. Considering that this situation is related to the structural stress redistribution of culverts after the cracking load, the influence of cracking on the bearing capacity of the culvert is not considered in the finite element, so the relative error in the plasticity work phase is large. In summary, the finite element model is consistent with the experimental conclusions of the scale model test by comparing the displacement data of the round hinged $\mathrm{BC}$ structure and the integral BC structure, which indicates that the finite element model is effective.

4.3. Comparative Analysis of Mechanical Properties of Reinforcement. The mechanical properties of reinforcement in the round hinged $\mathrm{BC}$ and the integral $\mathrm{BC}$ are compared and analyzed with the cracking load of the round $\mathrm{BC}$ as the loading value. The axial force diagram of reinforcement in the two directions of $\mathrm{BC}$ is extracted by taking the direction of top slab span as $X$-axis and the direction of side wall height as $Y$-axis, and the results are shown in Figures 12 and 13.

It can be seen from Figure 12 that the axial force distribution of the round hinged $\mathrm{BC}$ and the integral $\mathrm{BC}$ is the same in the $X$-axis direction, and the maximum axial force is generated in the midspan section of the top slab. This also conforms to the law that BCs is caused by the tensile failure of the midspan section in the scale model test. The maximum axial force of the integral $\mathrm{BC}$ and the round hinged $\mathrm{BC}$ in the 


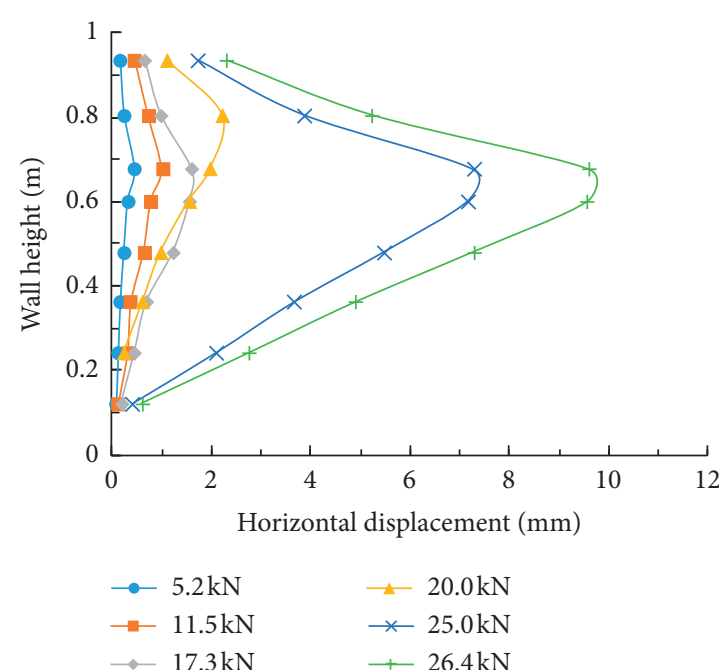

(a)

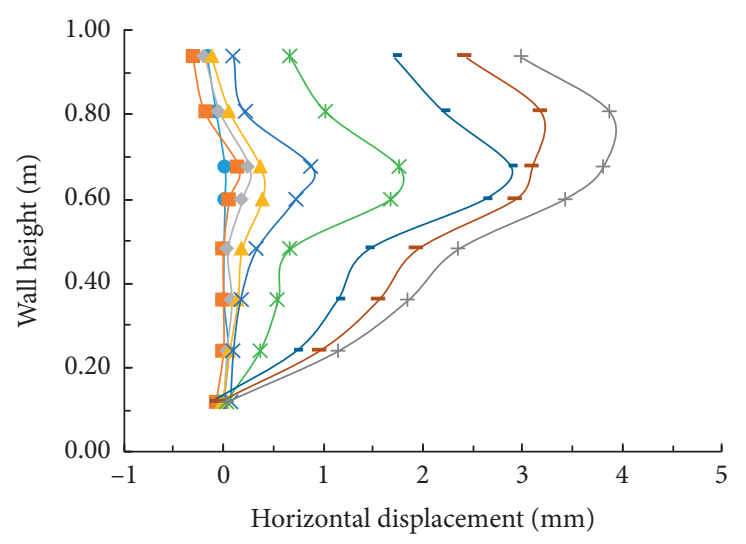

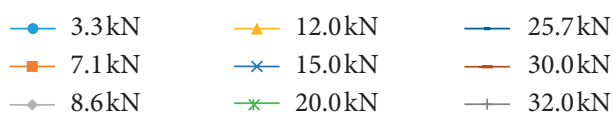

(c)
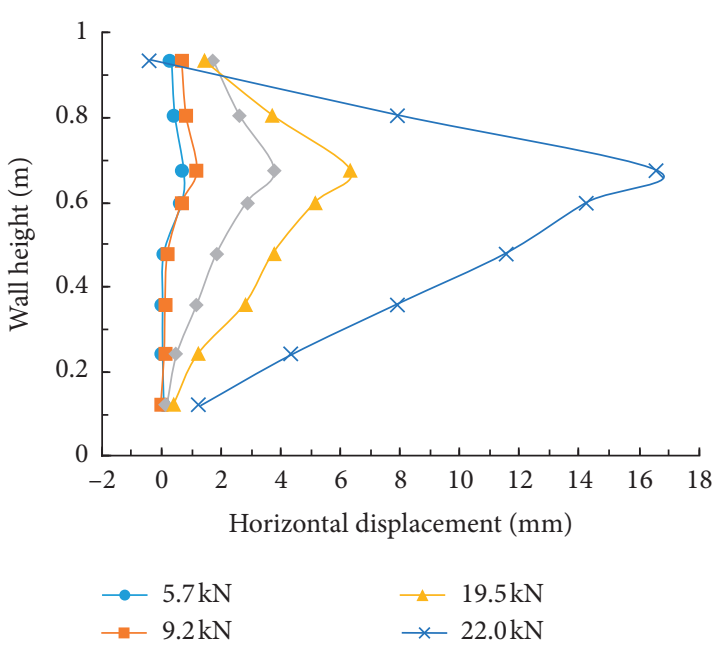

(b)

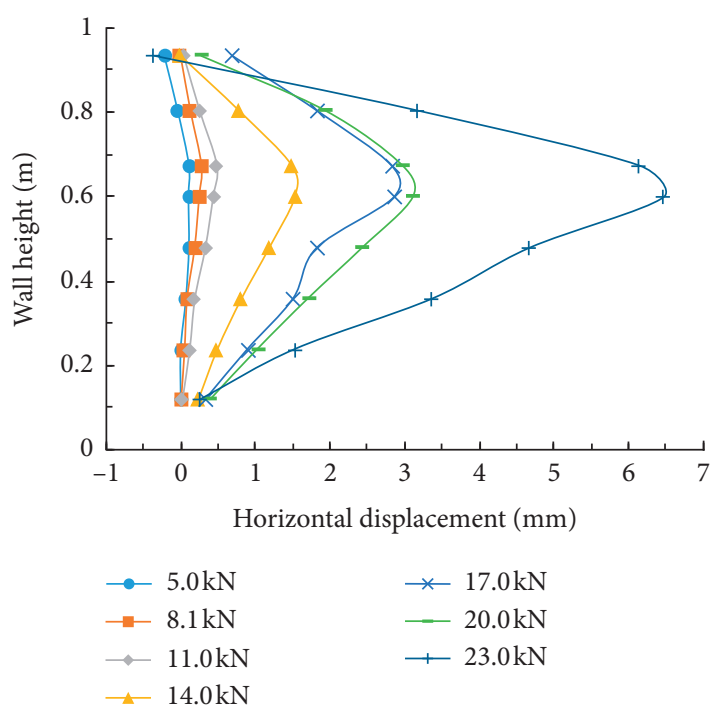

(d)

FIgURE 6: The displacement distribution rule of side walls of various models. (a) Flat seam type. (b) Round hinged type. (c) Integral type. (d) Mortise type.

$X$-axis direction is $495.037 \mathrm{~N}$ and $729.599 \mathrm{~N}$, respectively. The performance of the integral $\mathrm{BC}$ is better than that of the round hinged $\mathrm{BC}$.

Comparing and analyzing the axial force diagram of the reinforcement in Figure 13, it can be seen that the axial force distribution of the round hinged $\mathrm{BC}$ and the integral $\mathrm{BC}$ is greatly different in the $Y$-direction. The maximum axial force of reinforcement in the round hinged $\mathrm{BC}$ is generated at the bottom of the side wall. And the maximum axial force of reinforcement in the integral $\mathrm{BC}$ is generated at the top of the side wall, indicating that the change of the structural form has caused great changes in the mechanical properties of BCs. The maximum axial force of reinforcement in the round hinged $\mathrm{BC}$ structure is $453.235 \mathrm{~N}$ and the maximum axial force of reinforcement in the integral $\mathrm{BC}$ is $479.307 \mathrm{~N}$. The maximum axial force of reinforcement in the integral BC is 1.06 times that of the round hinged $\mathrm{BC}$, and the maximum axial force of the two $\mathrm{BCs}$ are basically the same.

4.4. Comparative Analysis of Mechanical Properties of Concrete. The first principal stress cloud diagram of the concrete in the calculation results of the round hinged $\mathrm{BC}$ and the integral $\mathrm{BC}$ is extracted with the round hinged $\mathrm{BC}$ cracking load as the loading value. The result is shown in Figure 14.

Analysis of the stress distribution in Figure 14 shows that the distribution law of the principal stress of the round hinged $\mathrm{BC}$ conforms to the experimental cracking phenomenon. The first principal tensile stress of the round hinged $\mathrm{BC}$ is mainly generated at the midspan position of the internal surface of the top slab and the bottom position of 


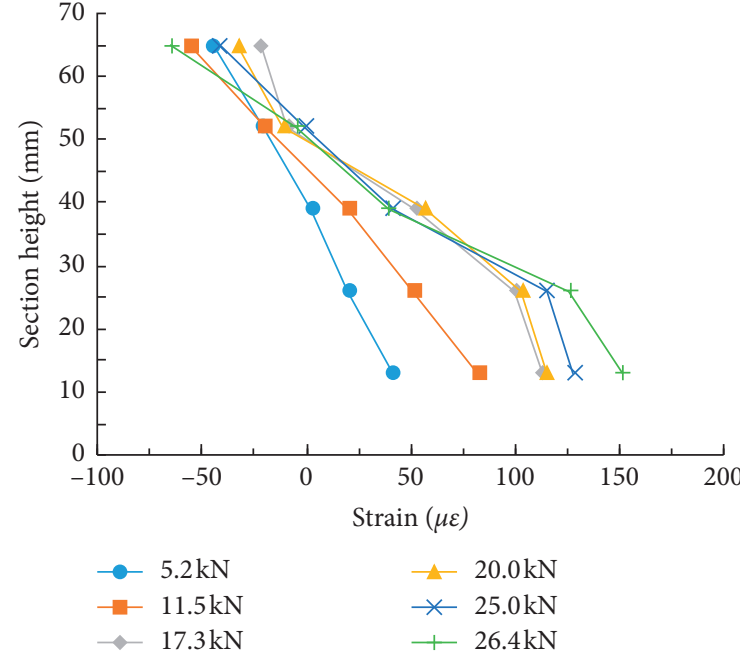

(a)

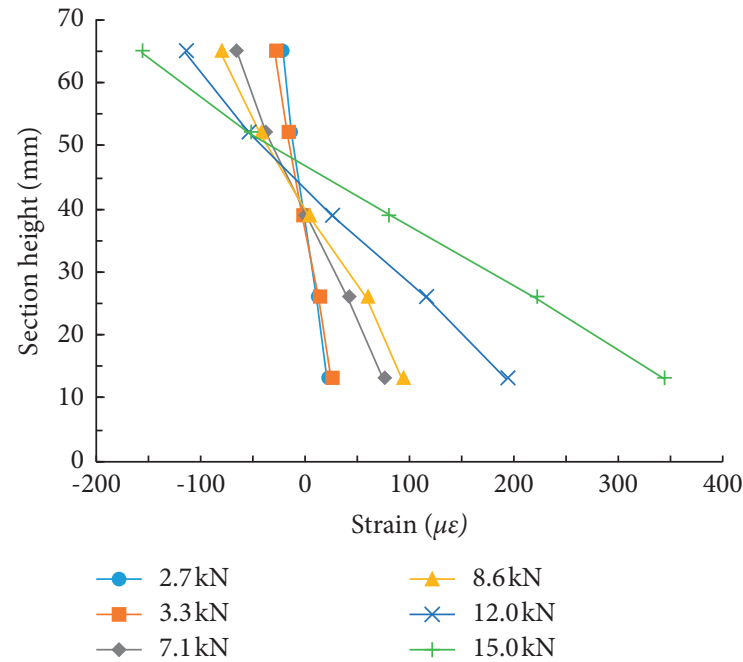

(c)

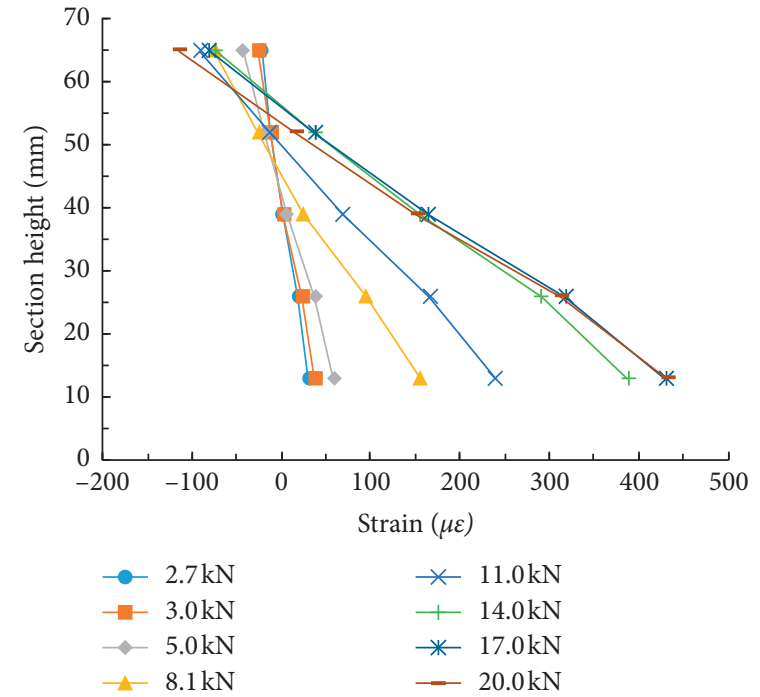

(b)

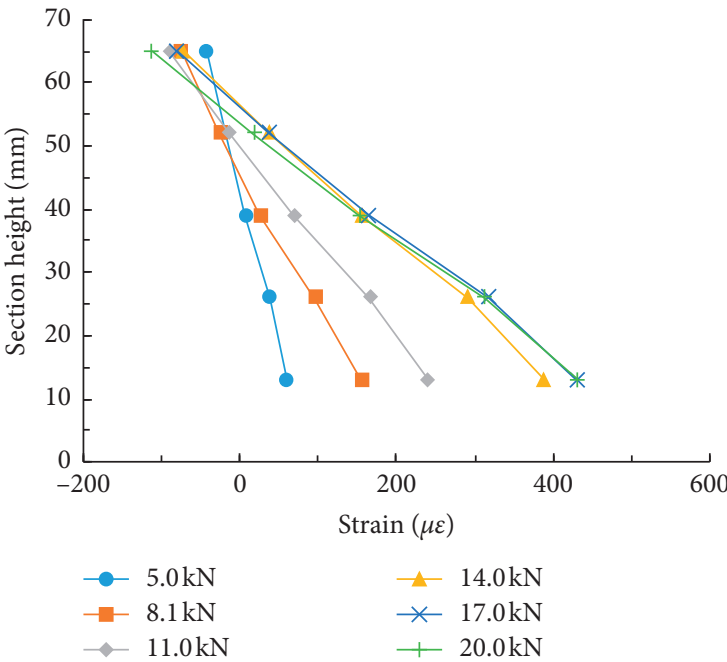

(d)

Figure 7: Variation law of strain of midspan section in top slab of various BCs. (a) Flat seam type. (b) Round hinged type. (c) Integral type. (d) Mortise type.

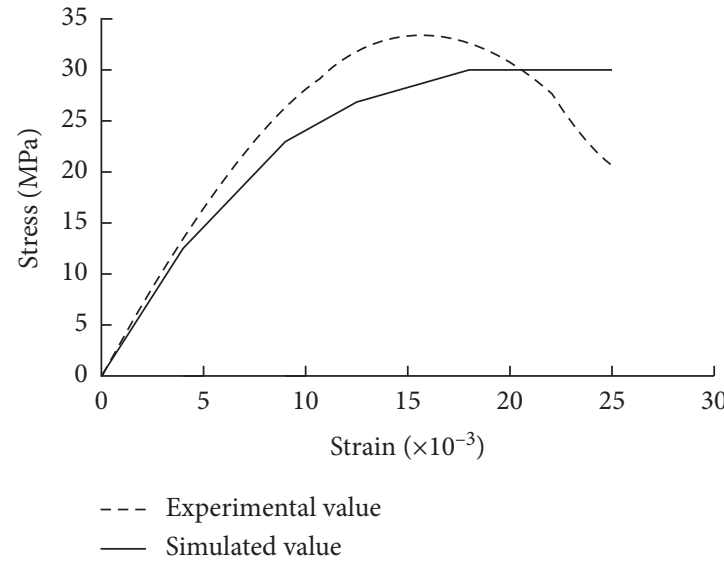

(a)

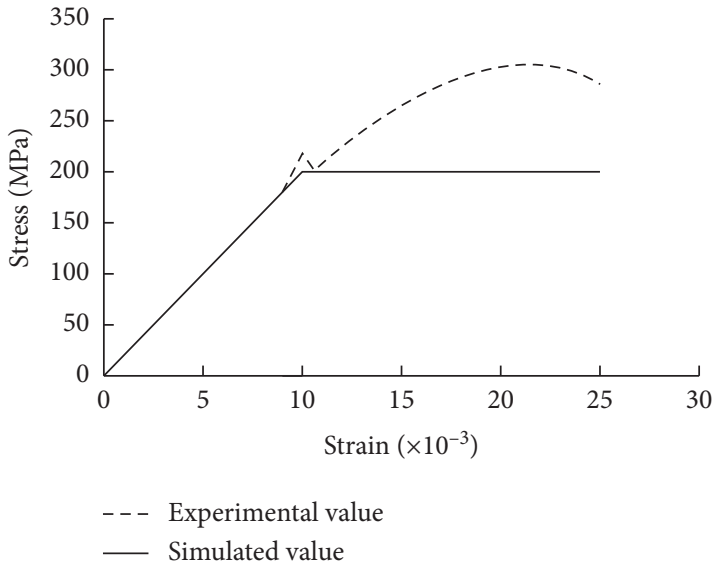

(b)

Figure 8: Constitutive model of materials. (a) The constitutive model of concrete. (b) The constitutive model of reinforcement. 


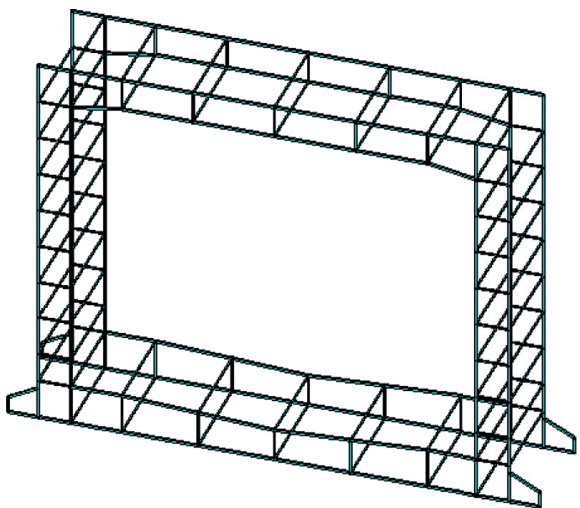

(a)

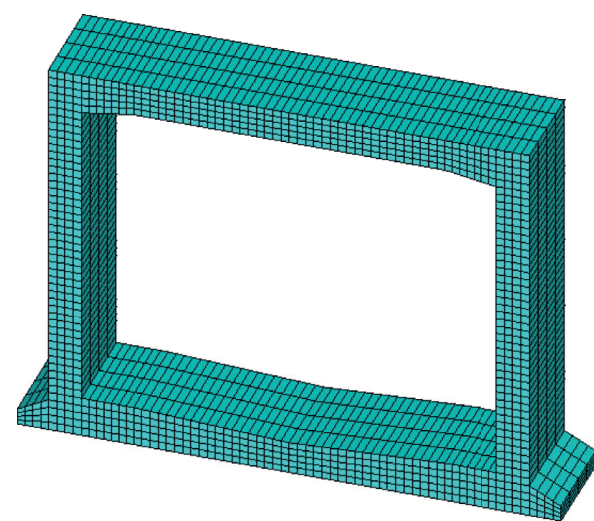

(b)

FIgURE 9: Finite element model of integral type BC. (a) Reinforcement model. (b) Concrete model.

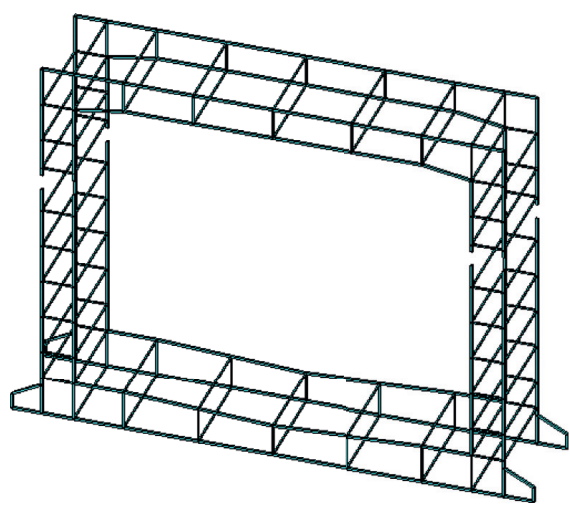

(a)

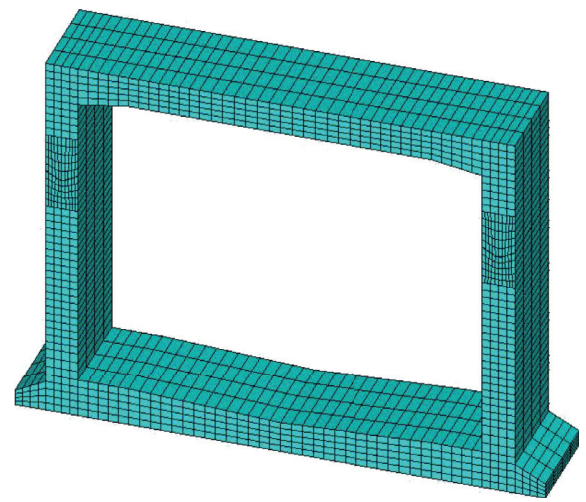

(b)

Figure 10: Finite element model of round hinged BC. (a) Reinforcement model. (b) Concrete model.

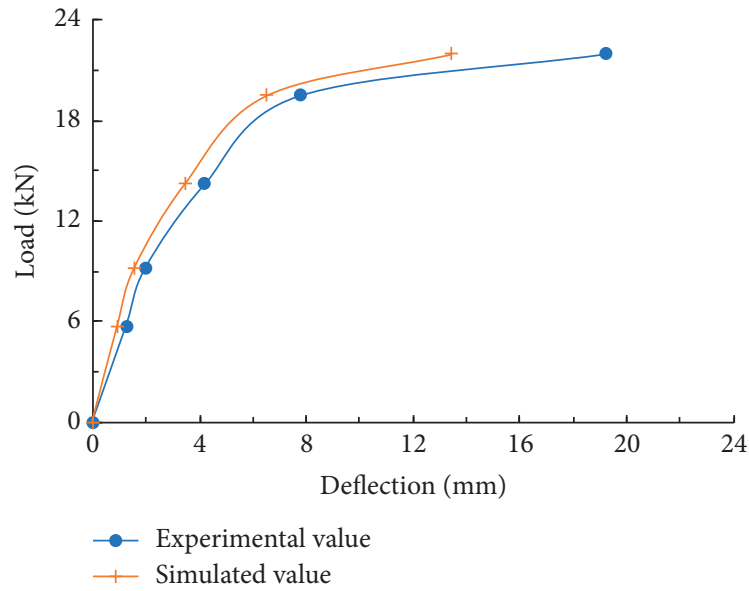

(a)

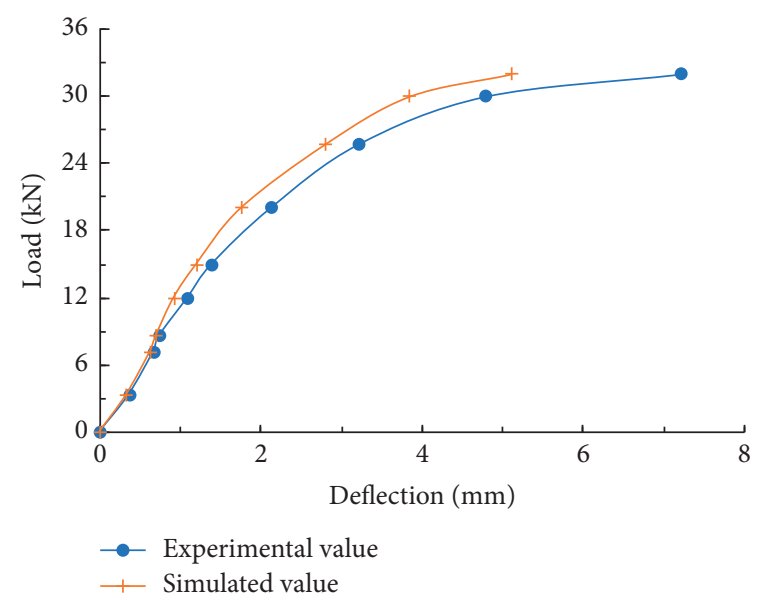

(b)

Figure 11: The midspan deflection-load curve of top slab of BCs. (a) Round hinged type. (b) Integral type.

the internal surface of the side wall, and the maximum tensile stress is $4.04 \mathrm{MPa}$. The first principal tensile stress of the integral $\mathrm{BC}$ is mainly generated at the midspan position of the internal surface of the top slab, the top of the external surface of the side wall, and the bottom of the internal surface of the side wall, and the maximum tensile stress is $2.81 \mathrm{MPa}$. By comparing the mechanical properties of the two structures, the existence of hinge joints separates top slab, side walls, and bottom plate, which changes the distribution law of the first principal tensile stress of BCs. 


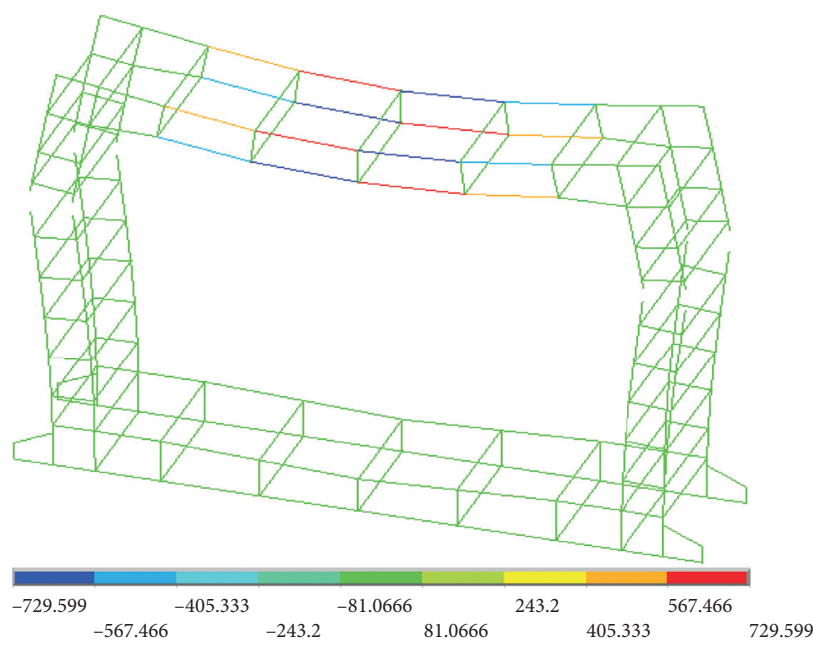

(a)

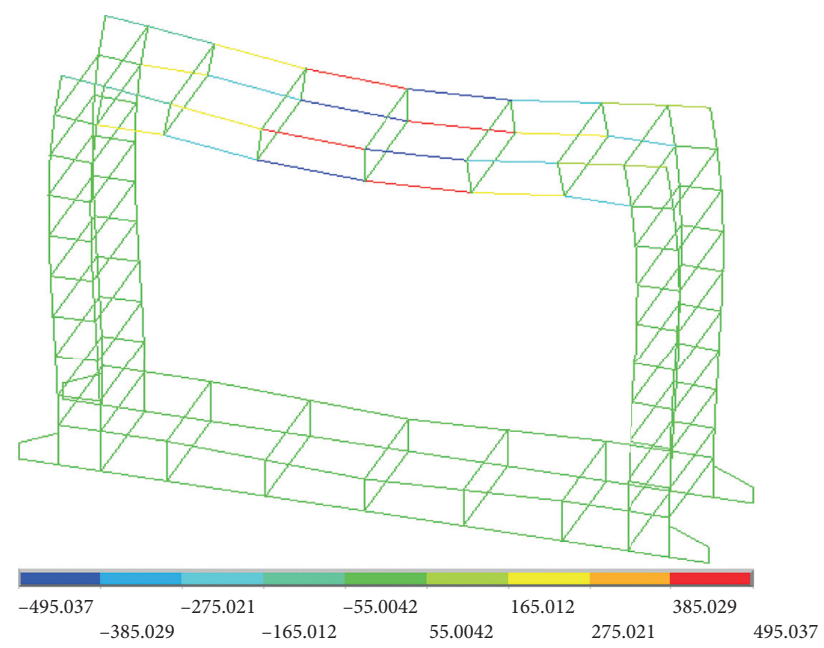

(b)

FIgURE 12: Axial force diagrams of BC reinforcement in the X-direction. (a) Round hinged type BC. (b) Integral type BC.

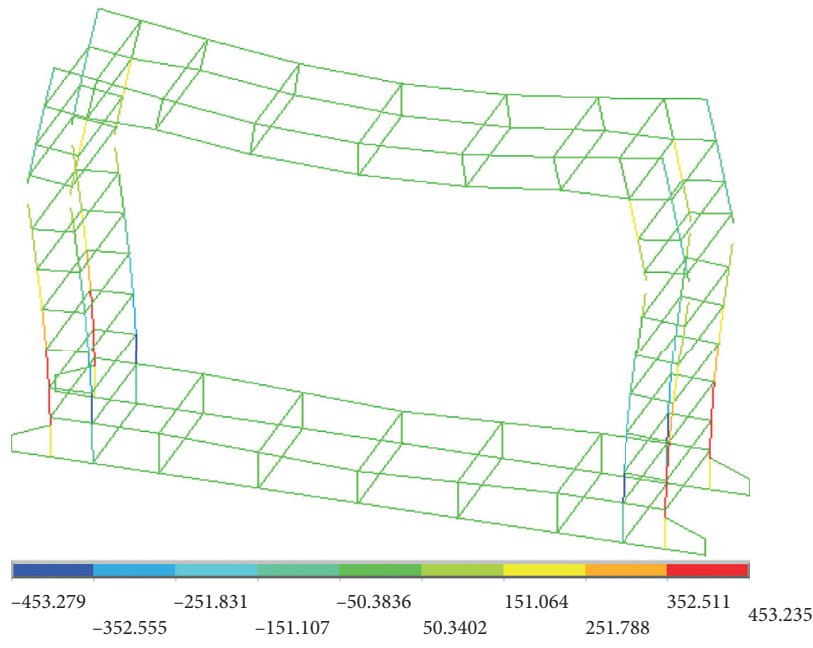

(a)

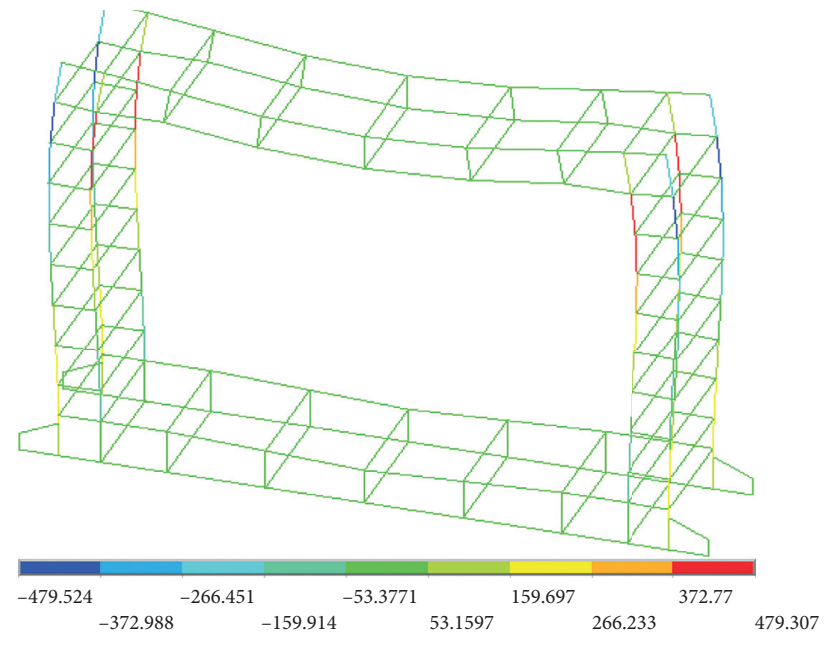

(b)

FIgUre 13: Axial force diagrams of BC reinforcement in the $Y$-direction. (a) Round hinged BC. (b) Integral BC.

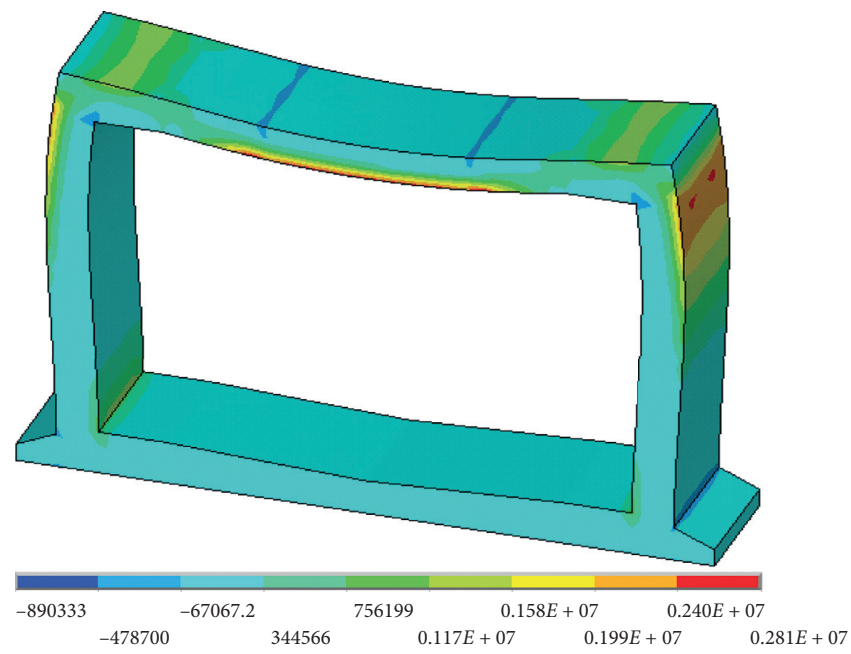

(a)

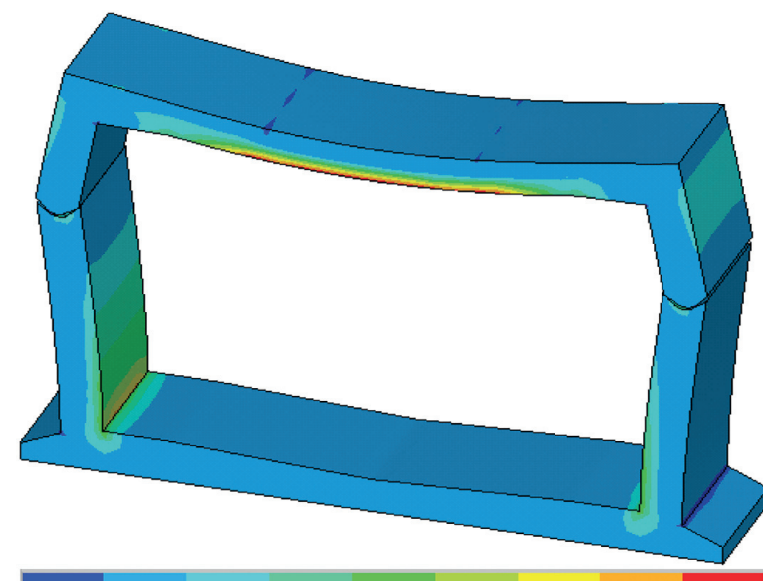

$\begin{array}{llllll}-645885 & 396314 & & 0.144 E+07 & 0.248 E+07 & 0.352 E+07 \\ & -124785 & 917414 & 0.196 E+07 & 0.300 E+07 & 0.404 E+07\end{array}$

(b)

FIGURE 14: The first principal stress cloud diagram of the concrete. (a) Integral BC. (b) Round hinged BC. 
Compared with the integral $\mathrm{BC}$, the round hinged $\mathrm{BC}$ produces a large horizontal displacement and rotation angle at hinge joints, releasing the first principal tensile stress of concrete on the top of the external surface of side walls and avoiding concrete cracking under the action of tensile force. The first principal tensile stresses at the bottom of the internal surface of the side wall of round hinged $\mathrm{BC}$ and integral $\mathrm{BC}$ is $2.08 \mathrm{MPa}$ and $1.58 \mathrm{MPa}$, respectively, and the first principal tensile stress at the bottom of the internal surface of the side wall of round hinged $\mathrm{BC}$ is 1.3 times that of the integral BC. The values of the two BCs are similar. Analysis of the local stress at hinge joints shows that the sliding and rotating contact behavior at hinge joints will result in the first principal tensile stress of the concrete at the internal surface of the side wall below the hinge joints. It can be known that contact behaviors at hinge joints are one of the main reasons leading to hinge joints cracking combined with the test phenomenon.

\section{Conclusions}

A scale model test based on different structural forms of prefabricated reinforced concrete BCs (flat seam BC, round hinged $\mathrm{BC}$, integral $\mathrm{BC}$, and mortise $\mathrm{BC}$ ) was proposed in this study. The failure mode of $\mathrm{BC}$ was the tensile failure under bending. At the same time, a finite element model based on nonlinear theory was established. Compared with the experimental results, the mechanical properties of reinforcement inside $\mathrm{BC}$ and the mechanical properties of concrete were studied. According to the section of the BC that was easy to break in the test process, valuable suggestions were provided for structural design. The following conclusions were obtained:

(1) The failure mode of $\mathrm{BC}$ was tensile failure of concrete on the internal surface of top slab under bending action. The largest load bearing capacity was the integral $\mathrm{BC}$, followed by the flat seam $\mathrm{BC}$ and the mortise $\mathrm{BC}$, and the worst was the round hinged $\mathrm{BC}$. In structural health monitoring, the width of the concrete crack on the internal surface of the top slab should be inspected. Then, the working performance of the concrete should be determined according to the specifications.

(2) The working state of BCs could be divided into elastic stage and plasticity state. The initial stiffness of the round hinged $\mathrm{BC}$ is less than that of the other three types of BCs. In the process of structural health monitoring, the working state of BCs could be determined by plotting the long-term deflection curve of the midspan section of top slab.

(3) The change of horizontal displacement of the side walls of BCs from bottom to top showed a regular pattern that increases first and then decreases. The maximum horizontal displacement should occur within the range of $(3 / 5 \sim 7 / 10) \mathrm{h}$ of the height of side wall for the integral structure, and the maximum horizontal displacement of the other three types of $\mathrm{BC}$ side walls occurred at hinge joints.
(4) Before BC was loaded to the occurrence of cracks, the bending normal strain distribution law of the crosssection of top slab of all kinds of BCs satisfied the flat cross-section hypothesis. However, as the load continues to increase, the presence of the crack caused the stress in the section to redistribute and neutral axis of the section rising in the vertical direction.

(5) The load-deflection curve of the midspan section of top slab obtained by the finite element model was consistent with the scale model test, which verified the validity of the finite element model. At the same time, the finite element model indicated that the sliding and rotating contact behavior at hinge joints would cause the first principal tensile stress of the concrete at the internal surface of the side wall below hinge joints. The contact behaviors at hinge joints were one of the main reasons leading to hinge joints cracking.

As a new type of structural form, prefabricated reinforced concrete BCs need to be further researched on its mechanical properties, such as the influence of vehicle live load on BCs and the influence of reinforcement ratio on the cracks on the internal surface of top slab. Furthermore, the mechanical properties of the $\mathrm{BC}$ in the engineering are also tested.

\section{Data Availability}

No data were used to support the findings of the study.

\section{Conflicts of Interest}

The authors declare that there are no conflicts of interest regarding the publication of this paper.

\section{Acknowledgments}

This work was supported by the National Natural Science Foundation of China (Grant no. 51978309), the Transportation Technology Program of Jilin Province of China (Grant no. 2018ZDGC-16, 2018-1-9), the Education Department's "13th Five-Year" Science and Technology Program of Jilin Province (Grant no. JJKH20190015KJ), the Fundamental Research Funds for the Central Universities and the Scientific and Technological Developing Scheme Program of Jilin Province (Grant no. 20200403157SF).

\section{References}

[1] X. Bian, X. Tang, W. Shen, D. Ling, and Y. Chen, "An experimental study on a culvert buried in granular soil subjected to vehicle loads," Advances in Structural Engineering, vol. 15, no. 6, pp. 1031-1040, 2012.

[2] Q. Ma, "Disease cause analysis and reinforcement technology for culvert at section K549+014 on Shuozhou-Huanghuagang," Railway Engineering, vol. 102, no. 1, pp. 84-86, 2017.

[3] M. K. Tadros, J. V. Benak, and M. K. Gilliland, "Soil pressure on box culverts," ACI Structural Journal, vol. 86, no. 4, pp. 439-450, 1989. 
[4] X. Yang and Y. Zhang, "Study on arch action and earth pressure theory for culverts under high embankment," Chinese Journal of Rock Mechanics and Engineering, vol. 24, no. 21, pp. 3887-3893, 2005.

[5] R. M. Bennett, S. M. Wood, E. C. Drumm, and N. R. Rainwater, "Vertical loads on concrete box culverts under high embankments," Journal of Bridge Engineering, vol. 10, no. 6, pp. 643-649, 2005.

[6] Y. S. Karinski, A. N. Dancygier, and I. Leviathan, "An analytical model to evalulate the static soil pressure on a buried structure," Engineering Structures, vol. 25, no. 1, pp. 91-101, 2003.

[7] H. Wang, W.-M. Qin, and Y.-Y. Jiao, "Stability assessment for highway with large-span box culvert jacking underneath: a case study," Canadian Geotechnical Journal, vol. 50, no. 6, pp. 585-594, 2013.

[8] J.-Y. Park, D.-S. Sohn, J.-H. Lee, S.-H. Kim, and J.-H. Jeong, "Influence of box culverts on behavior of jointed concrete pavements," Journal of Performance of Constructed Facilities, vol. 29, no. 2, p. 04014053, 2015.

[9] T. A. Wood, W. D. Lawson, P. W. Jayawickrama, and C. D. Newhouse, "Evaluation of production models for load rating reinforced concrete box culverts," Journal of Bridge Engineering, vol. 20, no. 1, Article ID 04014057, 2015.

[10] K. Kim and C. H. Yoo, "Design loading on deeply buried box culverts," Journal of Geotechnical and Geoenvironmental Engineering, vol. 131, no. 1, pp. 20-27, 2005.

[11] B.-g. Chen, J.-j. Zheng, and J. Han, "Experimental study and numerical simulation on concrete box culverts in trenches," Journal of Performance of Constructed Facilities, vol. 24, no. 3, pp. 223-234, 2010.

[12] S. L. Orton, J. E. Loehr, A. Boeckmann, and G. Havens, "Liveload effect in reinforced concrete box culverts under soil fill," Journal of Bridge Engineering, vol. 20, no. 11, Article ID 04015003, 2015.

[13] R. Acharya, J. Han, J. J. Brennan, R. L. Parsons, and D. K. Khatri, "Structural response of a low-fill box culvert under static and traffic loading," Journal of Performance of Constructed Facilities, vol. 30, no. 1, Article ID 04014184, 2016.

[14] A. K. Garg, A. Abolmaali, and R. Fernandez, "Experimental investigation of shear capacity of precast reinforced concrete box culverts," Journal of Bridge Engineering, vol. 12, no. 4, pp. 511-517, 2007.

[15] A. Abolmaali and A. K. Garg, "Effect of wheel live load on shear behavior of precast reinforced concrete box culverts," Journal of Bridge Engineering, vol. 13, no. 1, pp. 93-99, 2008.

[16] A. K. Garg and A. Abolmaali, "Finite-element modeling and analysis of reinforced concrete box culverts," Journal of Transportation Engineering, vol. 135, no. 3, pp. 121-128, 2009.

[17] M. Moradi, H. Valipour, and S. Foster, "Reserve of strength in inverted U-shaped RC culverts: effect of backfill on ultimate load capacity and fatigue life," Journal of Bridge Engineering, vol. 21, no. 2, Article ID 04015051, 2016.

[18] H. Maximos, E. Erdogmus, and M. K. Tadros, "Fatigue evaluation for reinforced concrete box culverts," ACI Structural Journal, vol. 107, no. 1, pp. 13-20, 2010.

[19] O. Abuhajar, H. El Naggar, and T. Newson, "Static soil culvert interaction the effect of box culvert geometric configurations and soil properties," Computers and Geotechnics, vol. 69, pp. 219-235, 2015.

[20] A. Shatnawi, G. Almasabha, and B. Tarawneh, "Structural behavior of concrete box culverts under deep burial," Journal of Pipeline Systems Engineering and Practice, vol. 8, no. 4, Article ID 04017025, 2017.
[21] P. Castaldo, D. Gino, and G. Mancini, "Safety formats for non-linear finite element analysis of reinforced concrete structures: discussion, comparison and proposals," Engineering Structures, vol. 193, pp. 136-153, 2019.

[22] Z. Li, C. Wang, H. Su, S. Shi, and P. Wang, "Mechanical property of tenon-groove joints for metro station constructed by prefabricated structure," Zhongguo Tiedao Kexue/China Railway Science, vol. 36, no. 5, pp. 7-11, 2015. 